\title{
HUNGARIAN ARCHAEOLOGY
}

E-JOURNAL • 2021 SUMMER

\section{DIGITAL GEOGRAPHIES AND VIRTUAL LANDSCAPE ARCHAEOLOGY}

Reconstructing the Iron Gates Castle System Under the Miasma of COVID-19

\author{
JASON SNIDER \\ Hungarian Archaeology Vol. 10 (2021), Issue 2, pp. 47-55. https://doi.org/10.36338/ha.2021.2.3
}

The Iron Gates gorge system is formed by the convergence of the Carpathians and Balkan mountain ranges that collide and plunge directly into the Danube River (Fig. 1). The geographical conditions of this region have created a frontier zone in different periods, and the historical context of this article deals specifically with the period between 1429 and c. 1435 when this castle system was placed under the control of a contingent from the Teutonic Order to help defend the Kingdom of Hungary against an impending Ottoman invasion. The Teutonic Order's mission was a military expedition and King Sigismund's use of a contingent from the Teutonic Order as a military force in this region was a part of his overall strategy to protect his kingdom from further invasion by Ottoman armies under Sultan Murad II (1404-1451). The Danube river, itself, at this time served as the frontier between the Kingdom of Hungary and the recently conquered Ottoman terri-

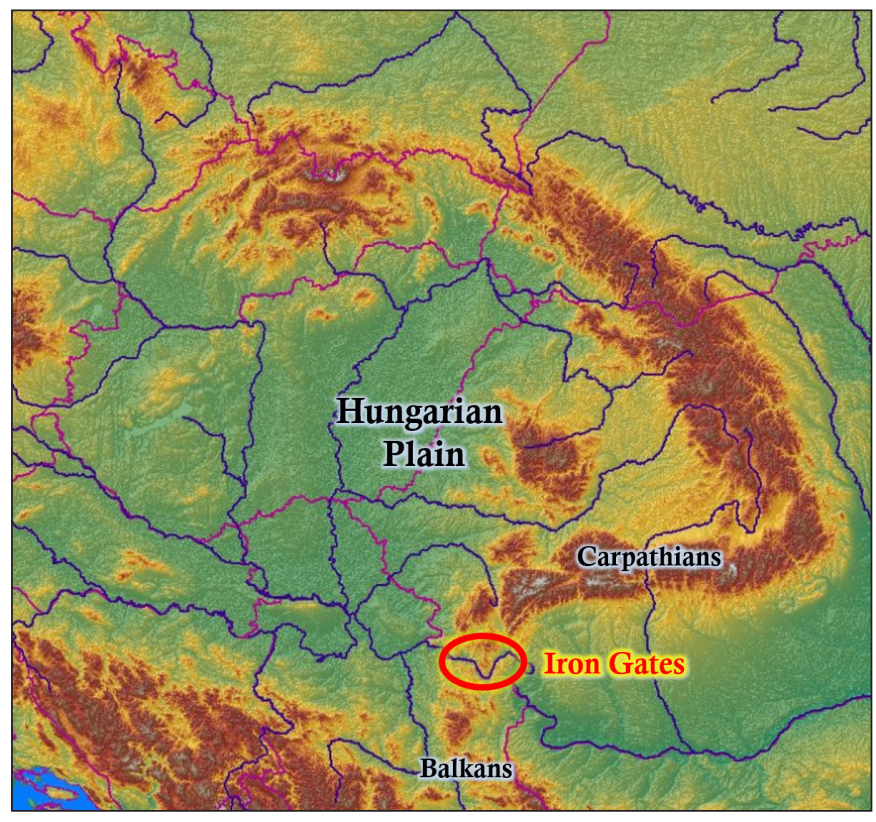

Fig. 1. Map of the Iron Gates in relation to surrounding terrain tory on the southern bank. The theme of this article centers on the application of traditional techniques of landscape archaeology to perform a military analysis of these fortifications in the Iron Gates castle chain using more novel avenues of research-given travel bans and other restrictions brought about by the on-going Corona-19 crisis.

Keywords: landscape archaeology, military analysis, castle, fortress, medieval fortification, Teutonic Order, Sigismund of Luxembourg, Murad II, Ottoman Wars, Iron Gates, Porțile de Fier, Đerdapska klisura, Eisernes Tor, Vaskapu

\section{THE PRE-EXISTING CONDITIONS}

Both military strategists and landscape archaeologists approach the exploitation and interpretation of terrain in complex, systematized manners. In many ways these approaches are similar, though the various objectives for the former requires an active result: to employ the natural environment for future action, while the latter seeks a more passive outcome: to decipher the same process for past actions within the conditions in which they had once existed. Making a very large assumption and then putting that aside for the moment - that it truly is possible through a multidisciplinary approach to recreate a past terrain - another precarious question arises. Would it be possible (during a time of restricted travel brought about by a world-wide pandemic) for an archaeologist/historian to use this approach to begin with that reconstructed, older landscape, and assess the military effectiveness (tactically and strategically) of manipulating that landscape by means of constructing a defensive chain of castles, all from a geographical distance? These questions will be addressed below in a discussion of my proposed methodology. I would maintain that if it is appropriate for landscape archaeologists to examine how ancient landscapes were exploited through human agency in a 
distant past, then it may be equally valid to go a step further and use the same field to examine how a castle chain was placed within a very constrictive landscape to consider whether it was done using a strategically sound method that best suited the highly volatile military situation in which it was employed.

A further related concern involves a longstanding historiographical controversy which speaks to a matter of territoriality. Is military history better served by academics coming from within the armed forces who have turned their battlefield expertise to the study of history, or trained historians applying their scholarly techniques onto military affairs (BIDDLe 2018; AlLison 2010)? For my part, I fall into the category of a researcher with a military background, and so my training and experience will shape how I deal with the questions posed above.

The focus of my doctoral research work concerns a military analysis of the castle chain on the part of the Danube River that stretches the length of the Iron Gates gorge (approximately $134 \mathrm{~km}$ long) (Fig. 2). Given my military background discussed above, I understand my approach to this topic as a kind of landscape archaeology through a military lens. Once the fortresses are placed in the historical landscape in which they had existed, my observations as to the military effectiveness of would be taken from the viewpoint of a soldier's analysis. Any observation would itself be scrutinized through primary sources such as military manuals which would have been available by the third decade of the fifteenth century to try and determine if there as any anachronism lying at the heart of the observation. The analysis is centered around the castles themselves (to include their garrisons), as individual material objects, but also as a working defensive system in total.

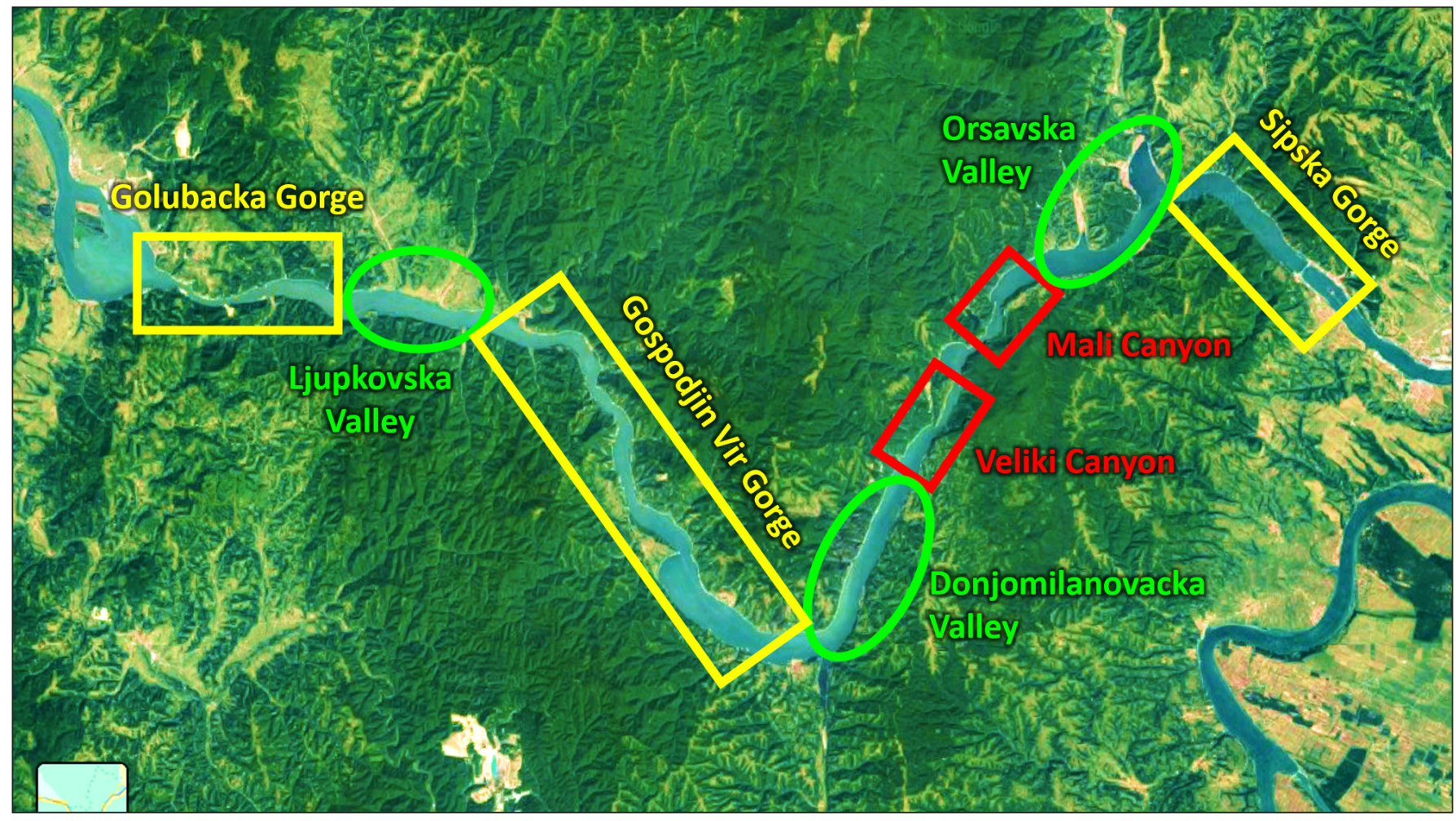

Fig. 2. Entire length of the Iron Gates system of gorges, canyons, and valleys

How, despite an uninterrupted two-year period of preparation, building, and strengthening brought by truce, were Ottoman forces able to break through at this very part of Hungary's entire frontier defense (spanning about two hundred kilometers along its southernmost borders with the buffer states of the Despotate of Serbia on the western flank, and the Voivodeship of Wallachia on the eastern flank) once the truce had ended? How, if the Iron Gates fortification system was meant as a key lynchpin between these two territories for Hungary's defense, did it fail? The Ottoman attack of 1432 began by testing the Serbian defenses at Belgrade and the surrounding area which successfully resisted, so Sultan Murad II (1404-1451) 
Jason Snider • Digital Geographies and Virtual Landscape Archaeology

withdrew to strike the defensive line at the Iron Gates. Common sense would dictate that this point should have been the strongest part of the entire defensive line, so why was the instantaneous breakthrough here, especially given the particularly forbidding terrain of the gorge itself? The purpose of my doctoral work is to attempt to answer these questions.

\section{HISTORICAL AND ARCHAEOLOGICAL APPROACHES IN THE RESEARCH OF THE CASTLES OF THE TEUTONIC ORDER AT THE IRON GATE}

Prior to 2020, there already were obstacles to analyzing how these castles related to their immediate landscapes. The twenty-four fortifications transferred to the control of the Teutonic Order in September 1429 were recorded in a contemporary document in the following way: Severyn, Insyl Saan, Vaskapu, Sente Peters, an unnamed fortress above Severyn, Goryn, Orsua, an unnamed fortress upriver from Orsua, Peczsch, an unnamed fortress above Peczsch, Lybko, Zynicze, Staniloucz, Dranko, Ybrasd, Soel, Ander Peczsch, Sand Ladislaen, Possesin, an unnamed fortress upriver from Possesin, Rybes, Myhalt, Halmas, and Ylied (Feneșan 2015) (Fig. 3). However, only the locations of seven of them are physically confirmable (on the River Danube: Severyn, Goryn, Zynicze, Dranko, and Sand Ladislaen; in the mountain passes: Myhalt, and Ylied). Part of this is due to the transience of memory where frontier lines move on, and fortresses no longer serve a military function. They become invisible through disuse, and the connection of name to actual location becomes broken. Likewise, part of it is due to the physical ravages of time, and the process of "architectural taphonomy" reads as: disuse leads to disrepair, to disintegration, and finally to burial and obscuration by vegetation. Therefore, the exact location becomes lost. The names from the 1429 report must be reconnected to their correct locations, and the locations of the sites physically lost must be discovered in order to begin to understand where to place these castles in a landscape for analysis. The solution would be to conduct exploratory fieldwork of the area, guided by local knowledge of the area from current inhabitants, or regional expertise from the Museum of Highland Banat (Muzeul Banatului Montan) in Reșița, the modern administrative center of the county (Caraș-Severin), for the western portion of the Iron Gates.

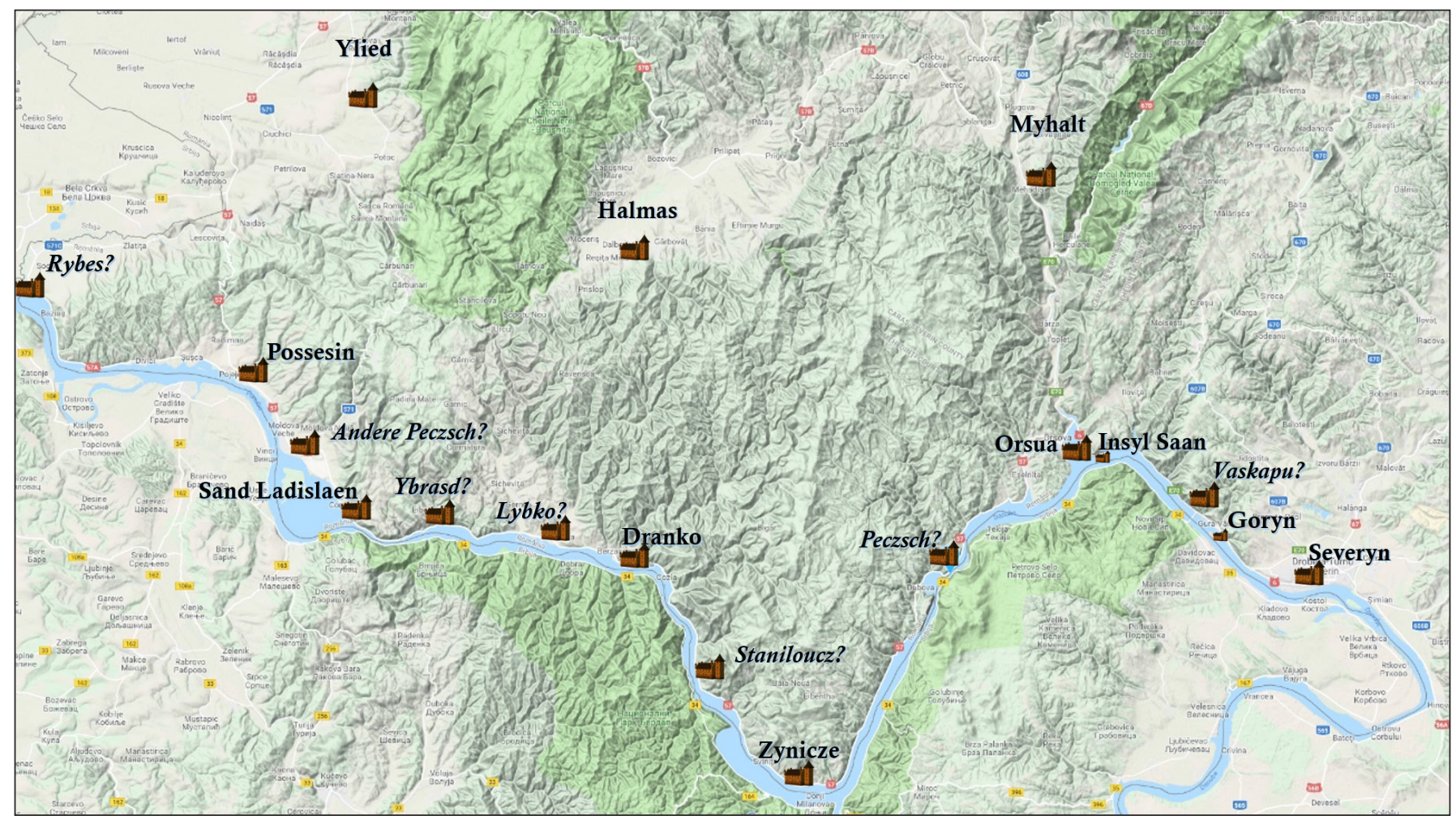

Fig. 3. Locations of known and suspected sites of the Teutonic Order's fortifications in the Iron Gates 
Jason Snider • Digital Geographies and Virtual Landscape Archaeology

However, in 1972, a third, larger obstacle materialized. The Iron Gates I Hydroelectric dam (Romanian: Porțile de Fier I, Serbian: Ђердап I/Đerdap I) was built between the modern towns of Orșova and Drobeta-Turnu Severin, inundating at least sixteen of the twenty-one castle sites located directly on the river Danube (United Nations 2011) (Fig. 4). This greatly hinders a physical search for foundations and other physical traces. Only the sites of Severyn and Goryn are known not to have been affected by the flooding caused by the dam as they are located downriver from it. The fortress of Sand Ladislaen, however, is a special case, as its chosen geographi-

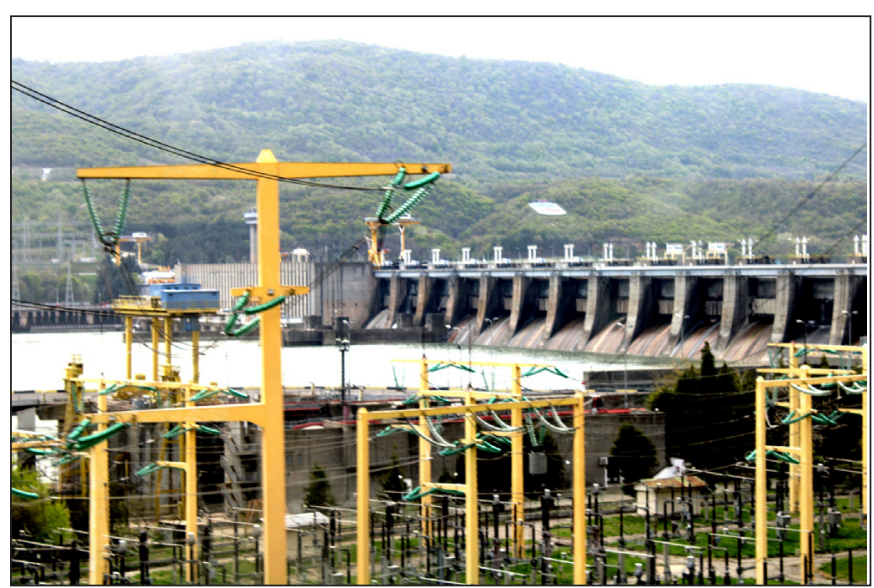

Fig. 4. The Iron Gates I Hydroelectric Dam cal location is set on a promontory two hundred fifty meters above the Danube's current water level. In his military study of the famous Siege of Golubac (1428, the same year of Sand Ladislaen's completion), László Veszprémy analyzes the connection of the fortress' construction to the siege of the castle Golubac (taken over by Ottoman troops in 1427), which greatly illustrates its strategic importance as a counterbalance in the ongoing Ottoman Wars (VESZPRÉMY 2009).

The rest of the Iron Gates riverine fortresses are known or are thought to be upriver from the dam along the shoreline of the old riverbank, and therefore affected in some way. Of these, only two of the known river sites (Zynicze and Dranko) are partially or almost completely covered by the new, raised, level of the Danube (Fig. 5). Though locatable, their immediate landscapes have disappeared (TEICU 2009). There is a further impediment to physically finding submerged sites. This is sediment deposition caused by the barrier of the dam itself, which greatly restricts its natural flow downriver and out of the region, further covering many sites. As the United Nations' Second Assessment of Transboundary Rivers, Lakes and Groundwaters specifically states:

"The construction of the Iron Gates has caused an alteration of the hydrological regime of the Danube River. Reduction of sediment transport capacity, leading to sediment deposition at certain parts and alteration of the character of the aquatic and riparian habitats, were among the main effects. Sediment deposition induced the gradual increase of high-water levels upstream, reducing the safety of the existing flood protection system." (UNITED NATIONS 2011)

To attempt to solve the overall problem of missing flooded locations and known submerged sites buried under decades of sediment deposition, a number of possible solutions have been identified, with varied levels of possibility. These include underwater excavation, as there is an example of a recent excavation very close to the site of the castle of Severyn (now modern Drobeta Turnu-Severin), which speaks to the feasibility of conducting research in this part of the heavily currented Danube (KAROVIĆ et. al. 2008). Another possibility would be Underwater LiDAR, as well as the more cost-effective SONAR technology (POPESCU \& IORDAN 2018).

Also, a further technology, geographic information system (GIS), would also provide additional avenues of research. This includes precise distancing, calculating accurate lines of sight, comprehensive interlocking fields of fire (MASSER 2019; JuŘíK, HeRMAN \& CHMELík 2017). It also provides image processing for geospatial analysis for digital mapmaking in itself, as well as offering the ability to represent the changes to landscapes themselves (MAVRAKIs 2014).

However, all of these solutions have become academic, so to speak. The idea of a physical investigation has had to have been shelved, in favor of more virtual analyses of past landscapes. Therefore, the field search will have to take on more of a role of confirmation for possible locations detected by the means discussed below, though most assuredly, it will also have to fulfill this pre-pandemic function in some cases. 


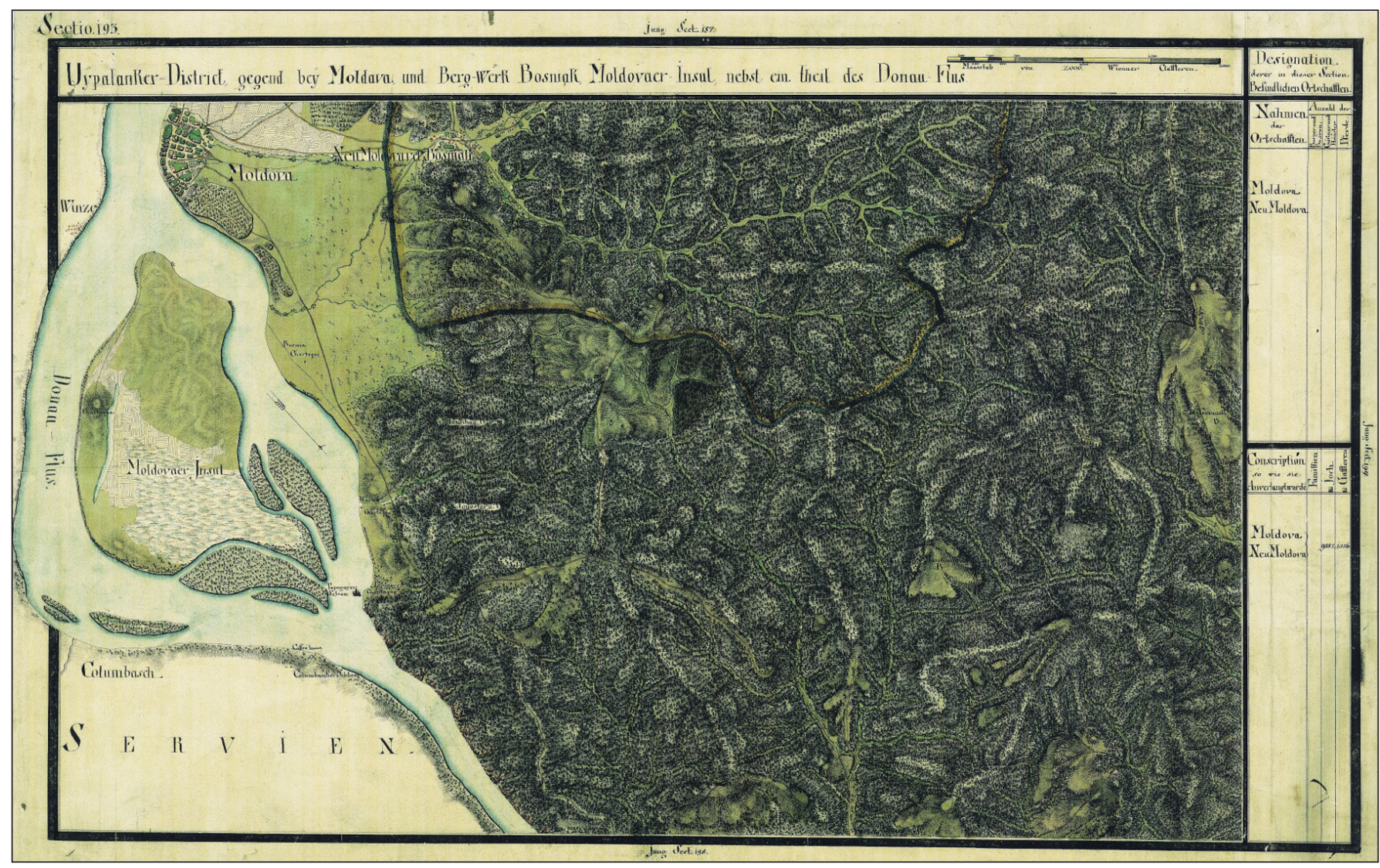

Fig. 5. Example Sheet 193 of the the First Military Survey of Emperor Joseph II

\section{A METHODOLOGY OF WORKAROUNDS}

The old techniques still make the best starting point - public health lock-down, or no. This necessitates document searches for listings of the various spellings of these castle names in at least five languages among deeds, diplomas, etc.; rummaging through mentions of sightings of mysterious ruins in old travel journals; as well as combing visual media for relevant sketches, woodcuts, or illustrations.

Afterall, it is the visual realm in which this work is grounded. To understand the tactical, strategic, and logistical relationships between these fortifications and their immediate terrains and regional environment in which they were placed in order to analyze the effectiveness of the Iron Gates castle chain (especially given its failure in the events of 1432), both the castles and their surroundings need to be observed together. Old maps become key, not only as a surrogate for physical observation because of COVID travel restrictions, but also as another source for finding possible site locations- like the documents, travel journals, and illustrations.

Pre-dam maps need to have two things to be useful. Regarding an understanding of the environment and terrain, the requirement is finding a representation of the area which is closest in date to 1432 as possible due to issues as riverbank erosion and course changes (though the latter is far less an issue than the former for the Danube in this mountainous region). Perhaps contradictory, both minuteness of scale (to reveal more details) and comprehensiveness of the area covered are needed. I have found the best compromise between the two comes from a subset of forty-eight map sheets out of a collection of 4,096 sheets comprising the First Military Survey of Emperor Joseph II (for example, Fig. 5). This survey was created between 1763 and 1785 to provide reliable maps for the Austrian Army. Therefore, its focus on military features in the landscape (such as fords, ferry crossings, ruins of fortifications, etc.) is perfect for this type of research (Fig. 6). It encompassed the entire territory under control of the Habsburg Empire at the time of production. Sheets are meant to be used in conjunction with each other as each one is a continuation of the other sheets that border it. This is a mapping survey that is: 1) a reliable map set, 2) covering the entire area of the Iron Gates, and 3) with the date of creation closest to 1432. 
Jason Snider • Digital Geographies and Virtual Landscape Archaeology

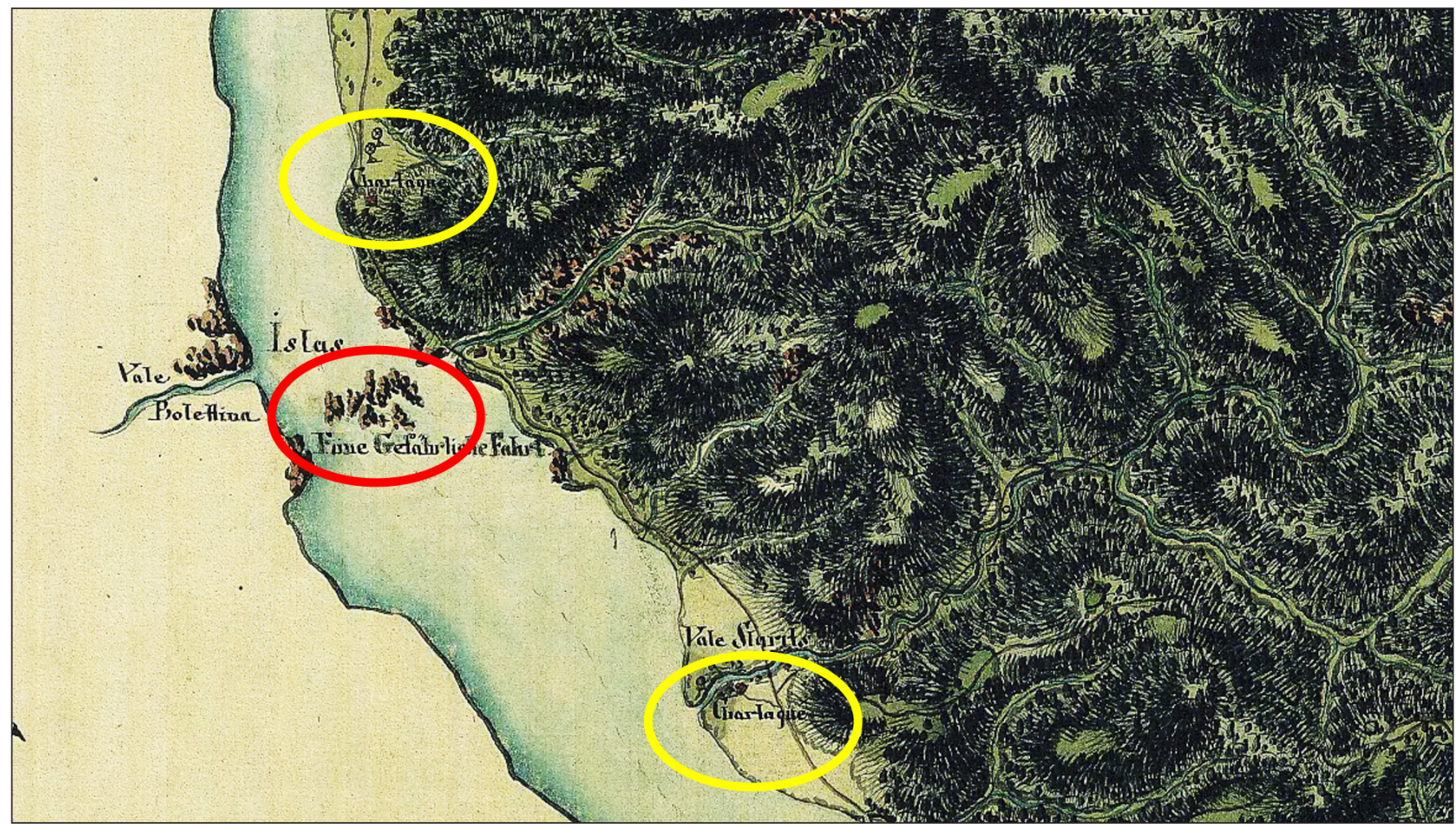

Fig. 6. Details of the First Military Survey illustrating navigational obstacles and fortification sites

Using a technique that I learned from my time in the United States Army, I have joined together (using heavy, transparent packing tape) these forty-eight sheets which were printed out on A3-sized paper (297 $\times 420 \mathrm{~mm}$ ) and laminated for durability. The problem with viewing maps on computer screens is that it is impossible to interpret focused, minute details represented within the map in the context of the larger

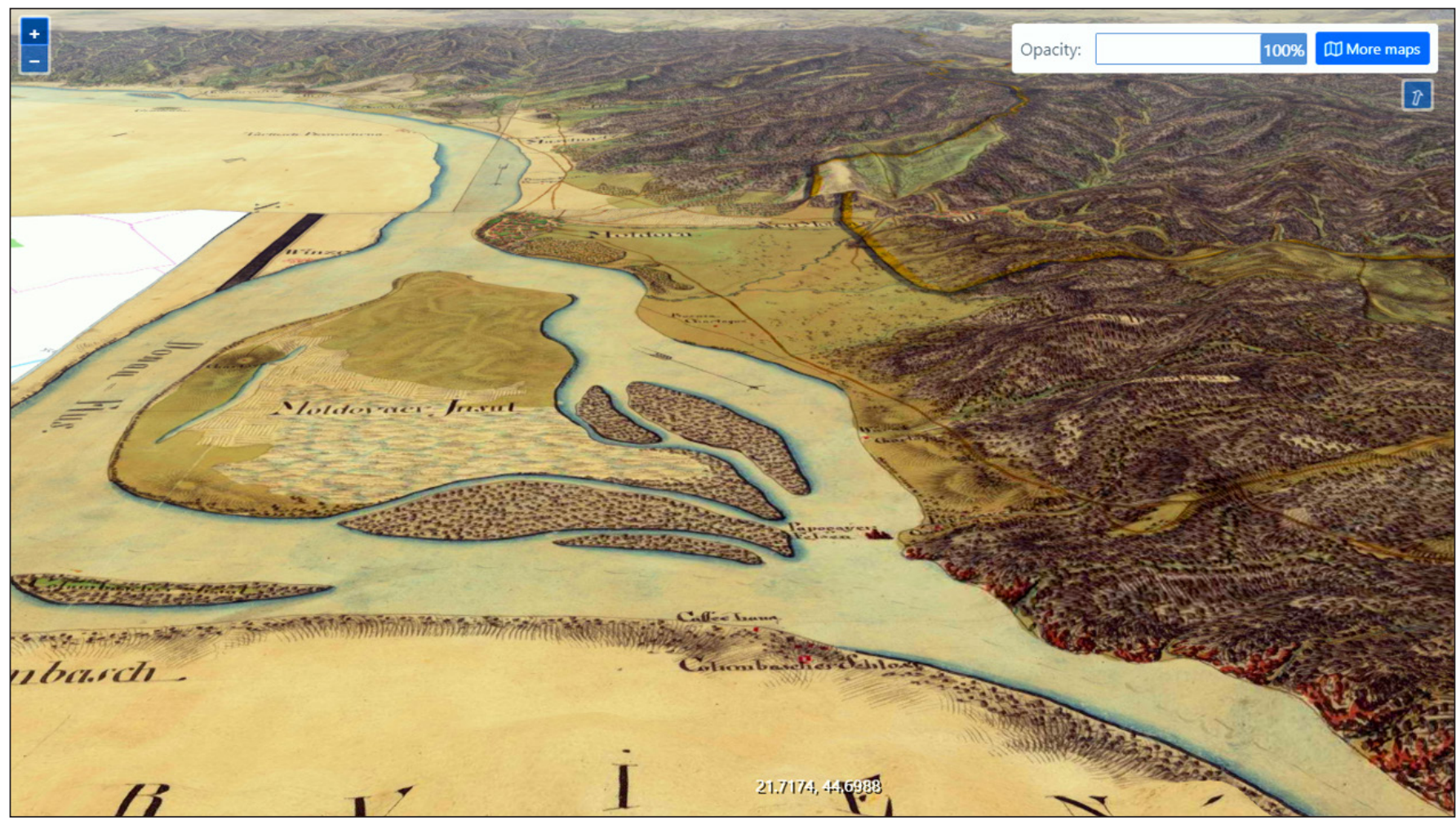

Fig. 7. Three-dimensional manipulation of the First Military Survey in Mapire website 


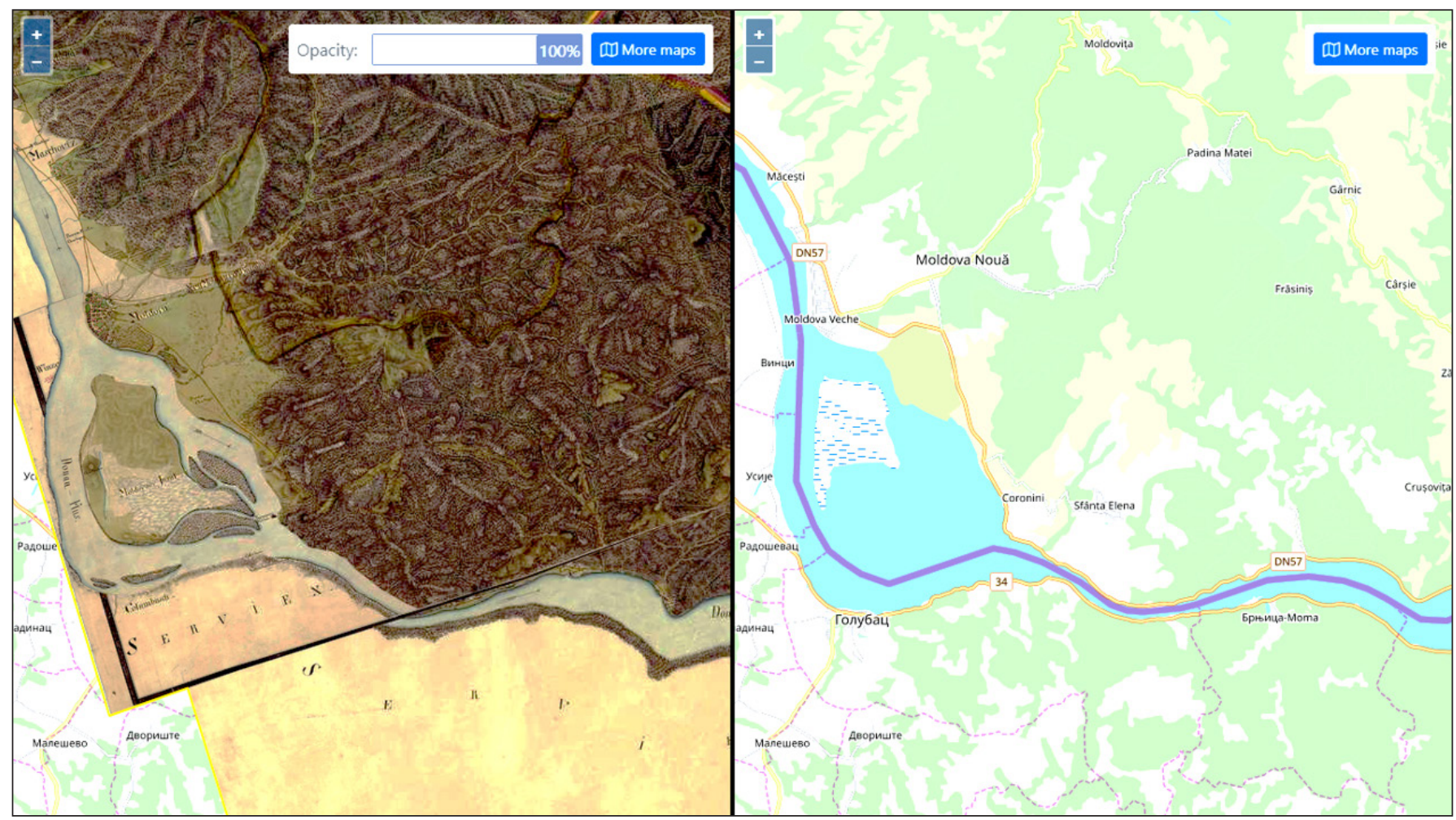

Fig. 8. Opacity manipulation of the First Military Survey overlay above the modern HERE map on Mapire website

picture of the entire area as a whole. On a fixed screen, one can either zoom in for detail, or zoom out for breadth, but not both simultaneously.

There is a further benefit for using this map set. The website Mapire connects all of the sheets from the First Military Survey (along with subsequent Military surveys) and digitally places them as a skin on a three-dimensional satellite map created by HERE Technologies (Fig. 7). As the Military Survey maps are hand-drawn and painted, details are not always perfectly aligned, but an attempt has been made to adjust these over the modern map by fixing known points that appear on both maps together and stretching or shrinking the area in between these few misaligned points. The result is that one can rotate the survey on all three axes, even laying it down to view the terrain as a bird might, flying to the horizon, as well as circle and zoom in and out of any point. Also, there is a function to precisely adjust the opacity of the Military Survey overlay to varying degrees (Fig. 8). This makes it possible to find points of interest that existed in real space in some form at the time of the Military Survey and were therefore represented upon it (like ruins that are no longer visible today), and then "look underneath" to see if that point of interest is now covered by the waters of the Danube. It also gives modern grid reference for points that can later be located on the ground through GPS positioning (see also: SKALO et al. 2011).

\section{SUMMATION}

It seems a little counter-intuitive that it is possible to make an observation like, "Watchtower $\mathrm{X}$ had a design flaw because it was placed too close to a large limestone outcropping to its Northwest that impeded its view of the river approach from that direction, all of which decreased its military effectiveness," without actually ever standing upon its ramparts. The realities of COVID-19 have curtailed much in normal life, placing field research even more out of reach. Luckily, there are solutions, both old and new technology has progressed enough so that there are a few workarounds, which are not perfect and must be verified later when international travel resumes once again.

Looking forward in my research under COVID, three-dimensional architectural design software (such as AutoCAD) will be useful to reconstruct fortresses using existing foundations and ground plans garnered 
Jason Snider • Digital Geographies and Virtual Landscape Archaeology

from the few archaeological excavations that were conducted just prior to the construction of the dam. This should allow for accurate-scale reconstructions of these military features to represent them as might have been in 1432. These can then be placed within a three-dimensional model of the medieval landscape in order to make observations for analysis, which then must be verified in person once the world opens itself up once again.

\section{RECOMMENDED LITERATURE}

Department of the Army (2007). The Infantry Rifle Platoon and Squad FM 3-21.8. Washington, DC: Department of the Army.

Engel, P. (2001). The Realm of St. Stephen: A History of Medieval Hungary, 895-1526. New York: St. Martin's Press.

Office of the Chairman of the Joint Chiefs of Staff (2018). DOD Dictionary of Military and Associated Terms (Washington DC: The Joint Staff.

Whelan, M. (2014). Sigismund of Luxemburg and the Imperial Response to the Ottoman Turkish Threat, $c$. 1410. PhD Dissertation, University of London.

\section{BIBLIOGRAPHY}

Allison, W. (2010). “Official Historians and Academic Historians: Perspectives on History: AHA,” American Historical Association, February 1, 2010. https://www.historians.org/publications-and-directories/ perspectives-on-history/february-2010/official-historians-and-academic-historians

Biddle, T. (2018). "The Role of Military History in the Contemporary Academy: Emplacements for The National WWII Museum: New Orleans.” Carlisle, PA: US Army War College, September 27, 2018. https:// www.nationalww2museum.org/war/articles/role-military-history-contemporary-academy

"Europe in the XVIII. Century." Mapire - The Historical Map Portal. Accessed May 3, 2021. https://maps. arcanum.com/en/map/europe-18century-firstsurvey/?layers $=$ osm $\% 2 \mathrm{C} 163 \% 2 \mathrm{C} 165 \& b b o x=1375255.01290$ 68845\%2C5428099.731704093\%2C2922340.465398852\%2C5917296.71272922

Feneșan, C. (2015). Cavalerii Teutoni în Banatul Severinului și la Dunărea de jos în prima jumătate a secolului al XV-lea [The Teutonic Knights in the Banat of Severin and the Lower Danube in the first half of the 15th century]. Timisoara: Cosmopolitan Art.

“Josephinische Landesaufnahme," Austria-Forum, May 1, 2020, https://austria-forum.org/af/AustriaWiki/ Josephinische_Landesaufnahme

Juř́k, V., Herman, L. \& Chmelík, J. (2017). "When the display matters: A multifaceted perspective on 3D geovisualizations.” Open Geosciences 9 (2017), 89-100. https://doi.org/10.1515/geo-2017-0007

Karović, G., Mihajlović, D. \& Vučković D. (2008). Trajan's Bridge on the Danube. The current results of underwater archaeological research. Proceedings of the 13th Annual Meeting of the European Association of Archaeologists, Zadar, Croatia, 2007, Session: Underwater Archaeology. Zagreb: Croatian Archaeological Society. 
Jason Snider • Digital Geographies and Virtual Landscape Archaeology

Mavrakis, A. (2014). "Profiling Rural Landmarks over Time: An Integrated Approach." Procedia - Social and Behavioral Sciences 147 (2014), 244-250. https://doi.org/10.1016/j.sbspro.2014.07.167

Masser, I. (2019). Geographic Information Systems to Spatial Data Infrastructures: A Global Perspective. New York: CRC Press. https://doi.org/10.1201/9780429505904

Popescu, G. \& Iordan, D. (2018). "An overall view of LiDAR and Sonar systems used in geomatics applications for hydrology." Scientific Papers. Series E. Land Reclamation, Earth Observation \& Surveying, Environmental Engineering 8 (2018), 174-181.

Skalo, J., Weber, M., Lipský Z., Trpáková, I., Santrucková, M., Uhlírová, L., Kukla P. \& Lipský, Z. (2011). "Using old military survey maps and orthophotograph maps to analyse long-term land cover changes - Case study (Czech Republic).” Applied Geography 31 (2011), 426-443. https://doi.org/10.1016/j. apgeog.2010.10.004

Țeicu, D. (2009). Cetăţi medievale din Banat (Medieval fortifications in Banat). Reşiţa: Muzeul Banatului Montan.

United Nations. (2011). Second Assessment of Transboundary Rivers, Lakes and Groundwaters in the UNECE Region. New York: United Nations Publications.

Veszprémy, L. (2009). “King Sigismund of Luxemburg at Golubac (Galamboc) 1428.” In Ch. Gastgeber et. al. (eds), Worlds in Change: Church Union and Crusading in the Fourteenth and Fifteenth Centuries (pp. 96-109). Transylvanian Review XVIII, Supplement 2. Cluj-Napoca: Romanian Academy. 